\title{
摩擦現象を利用したアルミニウムフォームの表面改質*
}

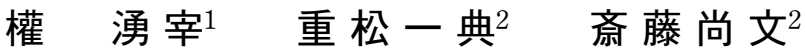 \\ 1韓国蔚山大学先端素材工学部 \\ 独立行政法人産業技術総合研究所サステナブルマテリアル研究部門
}

J. Japan Inst. Metals, Vol. 73, No. 7 (2009), pp. 527-532

(C) 2009 The Japan Institute of Metals

\section{Surface Modification of Aluminum Foams Using Friction Phenomena}

\author{
Yong-Jai Kwon ${ }^{1}$, Ichinori Shigematsu ${ }^{2}$ and Naobumi Saito ${ }^{2}$ \\ ${ }^{1}$ School of Materials Science and Engineering, University of Ulsan, Ulsan 680-749, Republic of Korea \\ ${ }^{2}$ Materials Research Institute for Sustainable Development, National Institute of Advanced Industrial Science and Technology (AIST), \\ Nagoya 463-8560
}

The surface region of the aluminum foams (trade name ALPORAS) was modified through the friction stir processing (FSP) which was performed by using friction phenomena with a high-speed rotating tool. The tool was rotated at speeds ranging from 820 to $2400 \mathrm{rpm}$, and plunged from the top surface of the aluminum foam, and then traversed at speeds ranging from 50 to 300 $\mathrm{mm} / \mathrm{min}$. The surface-modified zone (SMZ) had considerably smoother surface in comparison to the unprocessed zone (UZ). Especially for $1390 \mathrm{rpm}$ and $150 \mathrm{~mm} / \mathrm{min}$, the smoothest surface was obtained, which was attributed to the smaller amount of pores in the SMZ. In addition, a very dense layer was formed near the surface of the SMZ through the localized collapse and densification of the cell structure near the surface region, which was attributed to the friction phenomena with the high-speed rotating tool. The mechanical properties of the aluminum foams were significantly improved through the FSP. Especially for $1390 \mathrm{rpm}$ and $150 \mathrm{~mm} / \mathrm{min}$, the SMZ exhibited the highest average maximum indentation strength and energy absorption ability, which were equivalent to about 2.2 times the values of the UZ. The tool rotation speed and the tool traverse speed were very important parameters not only in controlling the surface morphology, but also in improving the mechanical properties of the aluminum foams. The FSP was a very effective technology for the remarkable improvement in the mechanical properties through the cell structure control of the surface region of the aluminum foams, without any dense skin materials.

(Received January 6, 2009; Accepted April 20, 2009)

Keywords: friction stir processing, porous metal, friction phenomena, surface modification, cell structure, aluminum foam, surface morphology, mechanical properties, indentation test, energy absorption

\section{1. 緒言}

多孔質金属材料は, 多量の気孔を含むセル構造を形成して いるため, 優れた軽量性, 衝撃吸収性, 吸音性, 断熱性など の多様で有益な特性を有している1-7)。 屯た，高分子多孔質 材料に比べても, 比強度が高い, 熱伝導度率が優れる, 融点 が高い，リサイクルが容易であるなどの様々な特長を示す。 そこで,このような多孔質金属材料は, 自動車, 医療, 建 築, 土木などの多くの産業分野で注目され, これらの材料に 関する研究が盛んに行われてきている，特に，多孔質金属材 料の作製プロセスに拉いては, 再現性の向上などのために新 しい製造技術の開発や従来技術の改善に関する研究が多く行 われた ${ }^{8-13)}$. また, 設計上の理由などで多孔質金属材料の特 性を調べるための研究も多く行われた ${ }^{14-18)}$. このような努 力の成果として, 高効率でコストの低減が可能な製造プロセ スが開発されるとともに, 多孔質金属材料の様々な特性が明 らかとなってきた。しかしながら，多孔質金属材料が示す多

* Mater. Trans. 50(2009) 192-196 に揭載
様で有益な特長を生かし，より多くの産業分野で実用部材と して実用化するためには, セル構造制御技術の確保や機械的 特性の改善など構造設計上要求される課題もまだ多く残され ている.

一方, 自然界でも長年にわたって進化しつづけ, 優れた機 能を発揮しているセル構造が八チの巣や木や骨などで多く観 察できる.このような自然界に抢けるセル構造体を観察して みると, セルの大きさや分布などがセル構造体中で均一では なく, 必要に応じて局部的に不均一になっている. 骨の構造 を一例として挙げてみると, 骨は外殼である緻密骨と中心部 の多孔質の海綿骨から構成された複合構造となっている.さ らに, 海綿骨の中でもセルの構造が均一ではなく, セルの大 きさや骨密度が局部的に異なる不均一な構造となっている. すなわち, 骨の中心部ではセルが大きくて骨密度が低いが, 外側に移るにつれてセルが小さくなるとともに骨密度が高く なっている，骨は，このようなセル構造を有することによ り, 必要な強度を確保しながら, 重量を軽減できる. 自然界 に存在しているこのような有効なセル構造を応用し, 多孔質 金属材料におけるセル構造を骨のように局部的に不均質化あ るいは傾斜化させることが可能になると，多孔質金属材料の 


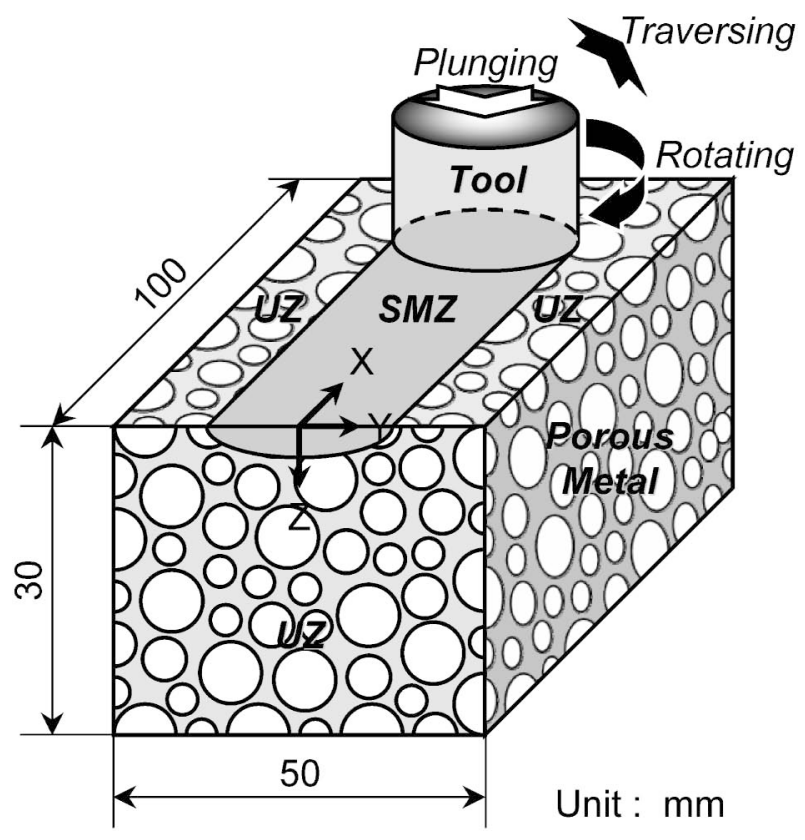

Fig. 1 Schematic illustration showing the basic principle of the friction stir processing (FSP) in this study. The surface modified zone and the unprocessed zone are labeled SMZ and UZ, respectively. And then, $\mathrm{X}, \mathrm{Z}$ and $\mathrm{Y}$ represent the tool traverse direction, the tool rotation axis direction, and the width direction of porous metal, respectively.

有益な特長を最大限に生かしながら，機械的特性の向上や構 造部材の軽量化なぞが期待できる.

そこで著者らは，Fig. 1 に示したように，多孔質金属材料 の表面改質方法として高速回転する工具と多孔質金属材料と の間で起こる摩擦現象を利用した摩擦擋汼プロセス (Friction Stir Process; FSP) ${ }^{19,20)}$ に着目した. 本プロセスでは, 円柱状の非消耗性工具を高速回転させながら多孔質金属材料 の表面から深さ方向に挿入した後, 移動させる.この間, 高 速回転している工具と多孔質金属材料との摩擦現象により摩 擦熱が発生し，多孔質金属材料の温度が上昇するとともに軟 化する.また，このように軟化した多孔質金属材料は高速回 転している工具により塑性変形される，その結果，多孔質金 属材料表面付近のセル構造が局部的に潰されることにより緻 密化が起こり, 表面改質領域 (Surface Modified Zone; SMZ) が形成されることになる.すなわち本プロセスは, 高速回転 する工具と多孔質金属材料との間で起こる摩擦現象を利用し て多孔質金属材料の表面付近を改質する方法である.

本研究では, アルミニウムフォームの機械的特性を向上す るために, 高速回転する工具とアルミニウムフォームとの間 で起こる摩擦現象を利用してアルミニウムフォームの表面付 近を改質するとともに, 工具の回転速度抢よび移動速度が表 面改質部の表面形状, セル構造打よび機械的特性に及ぼす影 響を調べた。

\section{2. 実 験 方 法}

供試材料として用いた多孔質金属材料は，主に閉気孔から 構成されたアルミニウムフォーム(ALPORAS, 神鋼鋼線工
業株式会社)であった。アルミニウムフォームは, 溶融アル ミニウムの粘性を向上させるためにカルシウム $(\mathrm{Ca})$ を添加 し, 水素化チタン $\left(\mathrm{TiH}_{2}\right)$ を発泡㓮として用いて作製したも のであった ${ }^{21)}$. アルミニウムフォームの形状は, Fig. 1 に示 したように, 長さ $100 \mathrm{~mm}$, 幅 $50 \mathrm{~mm}$ 抢よび厚さ $30 \mathrm{~mm}$ の 直方体であった. 表面改質用工具は, 材質が焼入机した工具 鋼 SKD61 であり, 直径 $15 \mathrm{~mm}$ の円柱状であった. 工具を それぞれ 820 から $2400 \mathrm{rpm}$ までの速度で右回りに回転させ ながら, アルミニウムフォームの表面から $2.6 \mathrm{~mm}$ の深さま で挿入した後, アルミニウムフォームの長さ方向 $(\mathrm{X}$ 軸方 向に 50 から $300 \mathrm{~mm} / \mathrm{min}$ の速度で移動させた。この際, 工具の回転軸 $(Z$ 軸) は工具の移動方向 $(X$ 軸方向) に対して 10 度傾けた。 また, すべての実験は大気中で室温下にて行 った.

表面改質部付近のセル構造を調べるために, 放電加工機を 利用してアルミニウムフォームの表面に垂直な方向に切断し た後, 切断面を研磨した. アルミニウムフォームの機械的特 性を調べるために押込久試験を行った。押込久試験では, 直 径 $10 \mathrm{~mm}$ の鋼球をアルミニウムフォームの表面から深さ 5 $\mathrm{mm}$ まで $1.0 \mathrm{~mm} / \mathrm{min}$ の一定な速度で圧入し, 荷重抢よび変 位の変化を調べた。

\section{3. 実験結果および考察}

\section{1 アルミニウムフォームのセル構造}

Fig. 2 は, 供試材料であるアルミニウムフォームの典型的 なセル構造を示す.アルミニウムフォームは, 約 $91 \%$ の気 孔率抢よび約 $0.24 \mathrm{~g} / \mathrm{cm}^{3}$ の見かけ密度を示した. 供試材料 のセル構造を調べるために, 放電加工機を利用して供試材料 を切断し研磨した後, 画像解析を行った結果, 閉気孔の約 $70 \%$ が直径約 1 から $4 \mathrm{~mm}$ の範囲で分布し, 平均直径が約 $2.4 \mathrm{~mm}$ であった。 また, セル壁の厚さは主に 100 から 250 $\mu \mathrm{m}$ の範囲で分布し, 平均厚さが約 $190 \mu \mathrm{m}$ であった.

\section{2 表面形状}

Fig. 3 は, 工具の移動速度を $150 \mathrm{~mm} / \mathrm{min}$ に一定とし, 工具の回転速度をそれぞれ (a) 820 , (b) 1390 および (c) 2400 $\mathrm{rpm}$ に変化させ表面改質したアルミニウムフォームの表面 外観を示す。未加工部 (Unprocessed Zone; UZ)に抢いて は, 表面改質前の供試材料のセル抢よび表面構造がそのまま 観察される. 一方, 表面改質部 (SMZ)では, いずれの工具 回転速度に扔いても, 高速回転する工具との摩擦により未加 工部とはまったく異なる表面外観を示した。すすおわち, 表面 改質部に扔いては供試材料に扔けるセル構造は観察されず, 表面が平坦化されることにより金属光沢が観察された。 た, 表面改質部における金属光沢部と開気孔部の比率を調べ るために画像解析を行った結果, 工具の回転速度 (a) 820 , (b) 1390 打よび(c) $2400 \mathrm{rpm}$ に扔いて開気孔部がそれぞれ約 50, 32 抢よび 46\%の面積率を示し，（b) 1390 rpm に扔いて 最も開気孔の少ない平坦な表面改質部が得られたことが分か った。このような結果から, 本プロセスに扔いて表面改質用 工具の回転速度はアルミニウムフォームの表面形状に影響を 


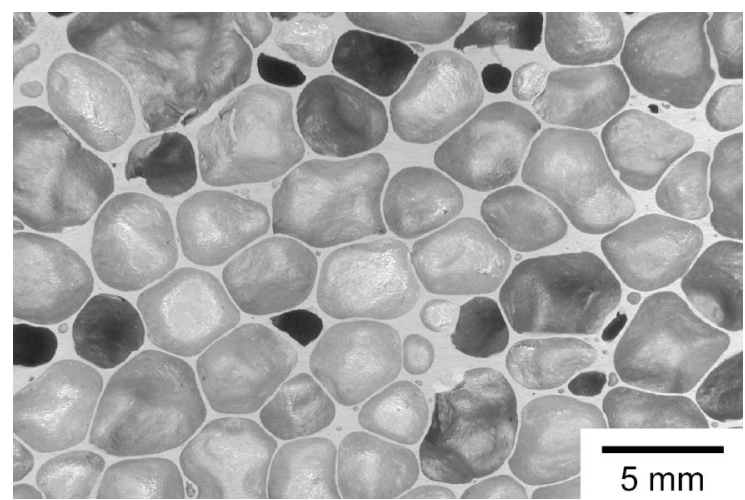

Fig. 2 Optical macrograph showing a typical cell structure of the aluminum foam used as the starting material in this study.
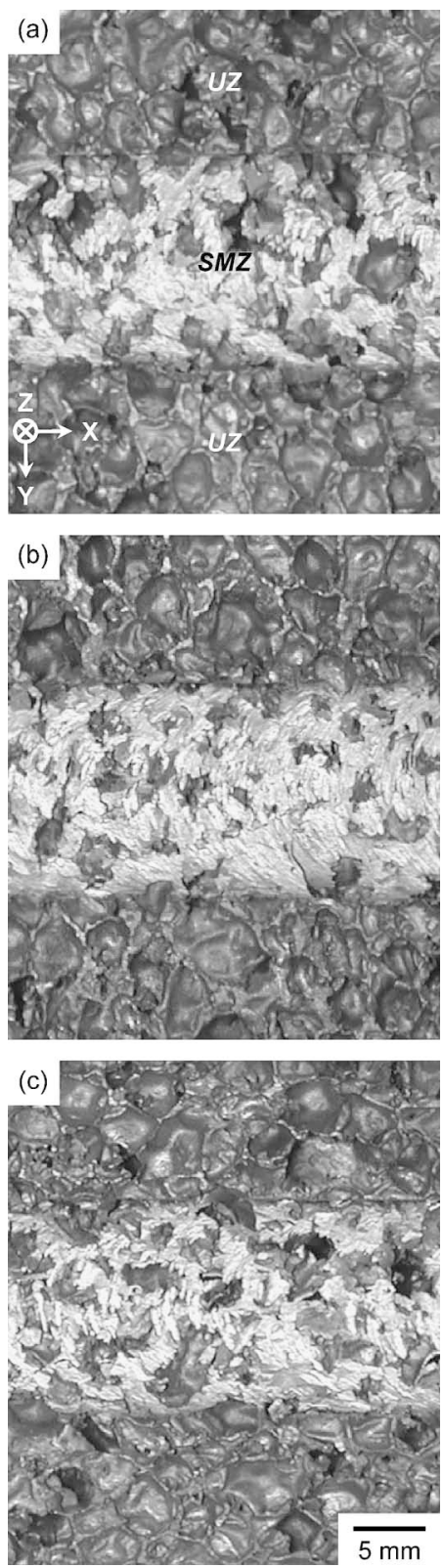

Fig. 3 Surface appearances of the aluminum foams surfacemodified at the tool rotation speeds of (a) 820, (b) 1390 and (c) $2400 \mathrm{rpm}$ under the constant tool traverse speed of $150 \mathrm{~mm} /$ $\min$
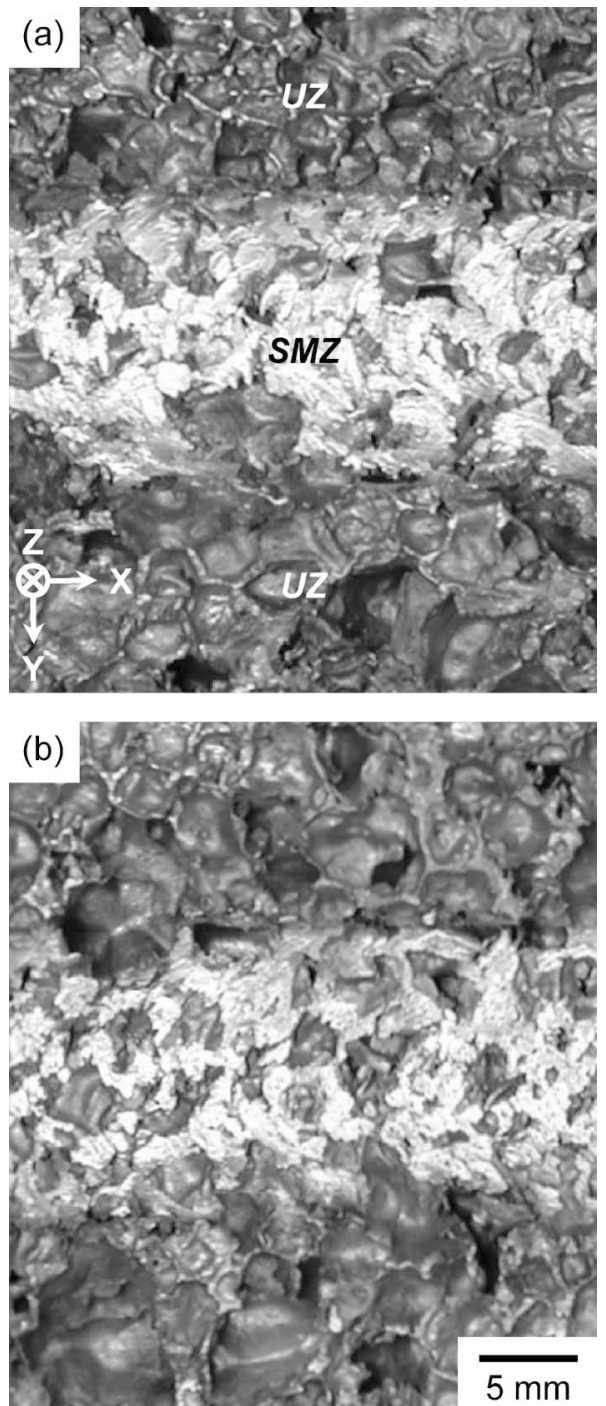

Fig. 4 Surface appearances of the aluminum foams surfacemodified at the tool traverse speeds of (a) 50 and (b) $300 \mathrm{~mm} /$ min under the constant tool rotation speed of $1390 \mathrm{rpm}$.

及ぼす重要なパラメータであることが明らかとなった，

Fig. 4 は, 工具の回転速度を $1390 \mathrm{rpm}$ に一定とし, 工具 の移動速度をそれぞれ (a) 50 および(b) $300 \mathrm{~mm} / \mathrm{min}$ に変化 させ表面改質したアルミニウムフォームの表面外観を示す. この場合においても, Fig. 3 と同様に, 表面改質部では供試 材料におけるセル構造は観察されず，平坦な表面が形成され たことにより金属光沢の表面改質部が得られた．また，表面 改質部における金属光沢部と開気孔部の比率を調べるために 画像解析を行った結果, 工具の移動速度 (a) 50 および(b) 300 $\mathrm{mm} / \mathrm{min}$ において開気孔部がそれぞれ約 58 および $56 \%$ の 面積率を示した。すなわち，工具の回転速度を $1390 \mathrm{rpm} に$ 一定とした場合では, Fig. 3(b)に示した工具の移動速度 $150 \mathrm{~mm} / \mathrm{min}$ において最も開気孔の少ない平坦な表面改質部 が得られた.このような結果から, 表面改質用工具の移動速 度も本プロセスにおいてアルミニウムフォームの表面形状に 影響を及ぼす重要なパラメータであることが明らかとなった。

以上の結果から, 摩擦撹拌プロセスはアルミニウムフォー ムの表面改質に有効であり, 表面改質用工具の回転速度抢よ 


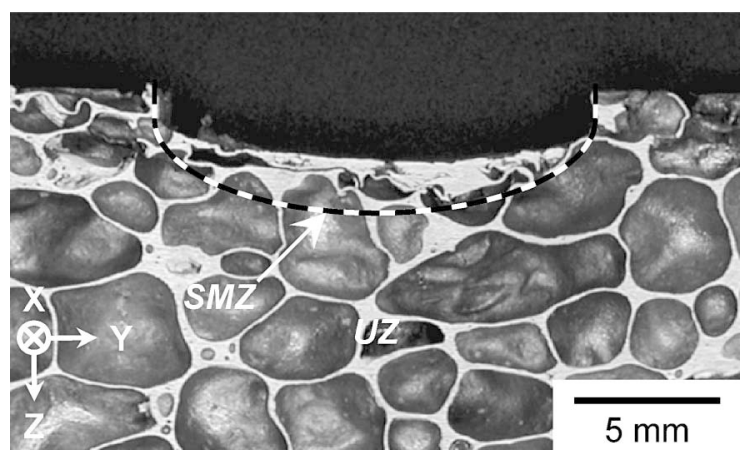

Fig. 5 Typical optical macrograph of the cross-sections perpendicular to the tool traverse direction of the surface-modified aluminum foam.

び移動速度は本プロセスにおいてアルミニウムフォームの表 面形状に影響を及ぼす重要なパラメータであることが明らか となった。

\section{3 表面改質部のセル構造}

Fig. 5 は，摩擦摚拌プロセスを利用して表面改質したアル ミニウムフォームにおける表面改質部付近のセル構造を示 す. 未加工部は, 表面付近の開気孔抢よび内部の閉気孔から 構成されていた。 一方, 表面改質部では, 未加工部の表面構 造とは異なり, 表面付近で非常に緻密な表面層が形成されて いた.このような結果から, 摩擦撹拌プロセス中に高速回転 する工具との摩擦により，アルミニウムフォームの表面付近 でセル構造が局部的に潰されるとともに，セル壁が塑性変形 することにより緻密な表面層を有する表面改質部が形成され たと考えられる．また摩擦擋拌プロセスを利用すると，他の 緻密なスキン材を用いずに，アルミニウムフォームの表面付 近に緻密な表面層の形成が可能であることが明らかとなった.

\section{4 機械的特性}

Fig. 6 (a)は，(1)未加工部とともに, 工具の移動速度を $150 \mathrm{~mm} / \mathrm{min}$ に一定とし, 工具の回転速度をそれぞれ(2)820, (3)1390 および(4)2400 rpm に変化させ作製したアルミニウム フォームの表面改質部の押込久試験における加重一変位曲線 を示す。また Fig. 6(b)は，工具の回転速度を $1390 \mathrm{rpm}$ に 一定とし，工具の移動速度をそれぞれ(5)50 および(6)300 $\mathrm{mm} / \mathrm{min}$ に変化させ作製したアルミニウムフォームの表面 改質部の押込久試験に抢ける加重一変位曲線を示す。いずれ の場合に抢いても, 加重一変位曲線は同様な傾向を示した. すなわち，押込久加重は明瞭な降伏現象を伴わず，変位量の 増加とともに徐々に増加する傾向を示した。

Fig. 7 は，(a)工具の回転速度抢よび(b)工具の移動速度が アルミニウムフォームの表面改質部の最大押込み加重に及ぼ す影響を示す。ここで, 最大押込み加重は Fig. 6 に示した 加重-変位曲線においてもっとも高かった荷重を示し，エ ラーバーは押し达久試験をそれぞれ 3 回ずつ行って得られ た最大值および最小值を示す。また，(a)抢よび(b)は，そ れぞれ工具の移動速度を $150 \mathrm{~mm} / \mathrm{min}$ に一定とした場合お よび工具の回転速度を $1390 \mathrm{rpm}$ に一定とした場合を示す.
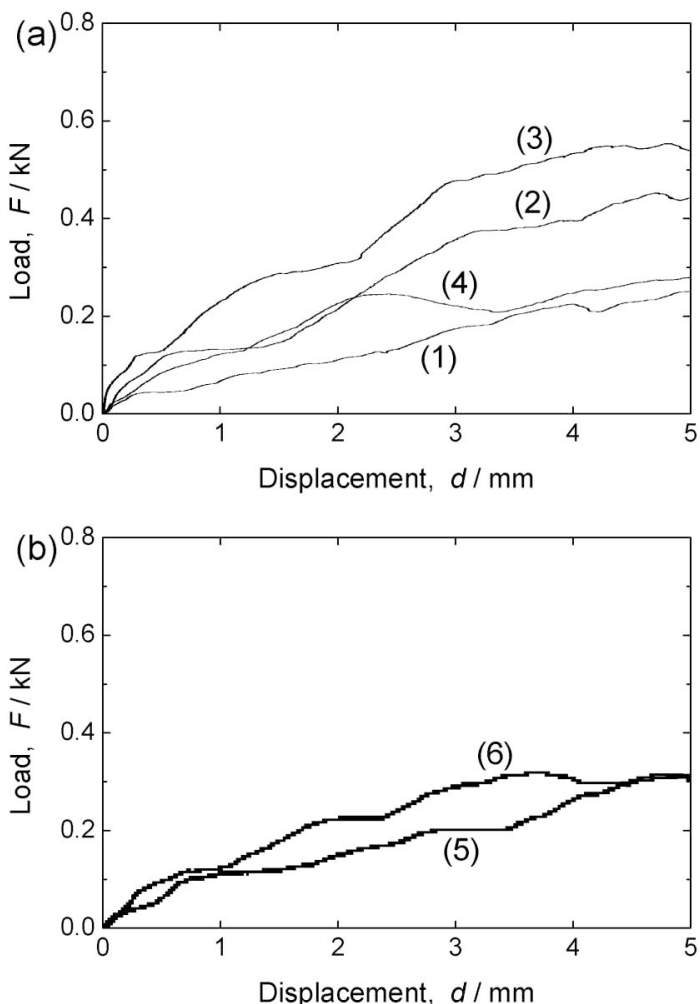

Fig. 6 Indentation Load-displacement curves of (1) the unprocessed zone (i.e., starting material), and the surface-modified zones of the aluminum foams produced at the tool rotation speeds of (2) 820, (3) 1390 and (4) $2400 \mathrm{rpm}$ under the constant tool traverse speed of $150 \mathrm{~mm} / \mathrm{min}$, and at the tool traverse speeds of (5) 50 and (6) $300 \mathrm{~mm} / \mathrm{min}$ under the constant tool rotation speed of $1390 \mathrm{rpm}$, respectively.
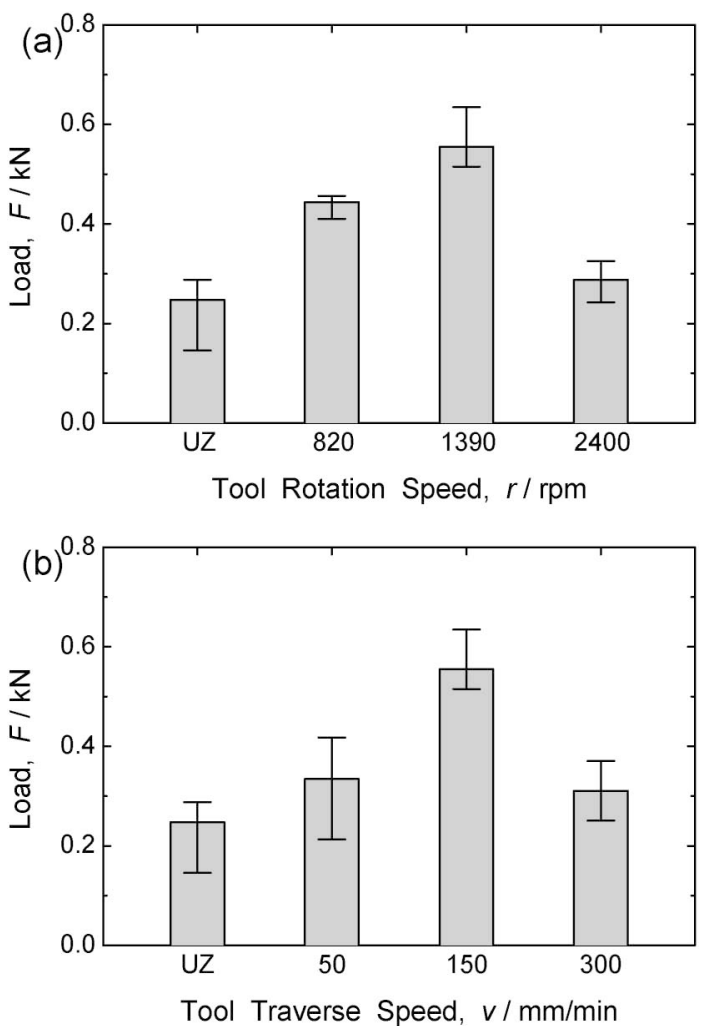

Fig. 7 Influences of (a) the tool rotation speed and (b) the tool traverse speed on the maximum indentation load of the surface-modified zone of the aluminum foams produced at the constant tool traverse speed of $150 \mathrm{~mm} / \mathrm{min}$ and tool rotation speed of $1390 \mathrm{rpm}$, respectively. The positive and negative error bars indicate the maximum and minimum values, respectively. 

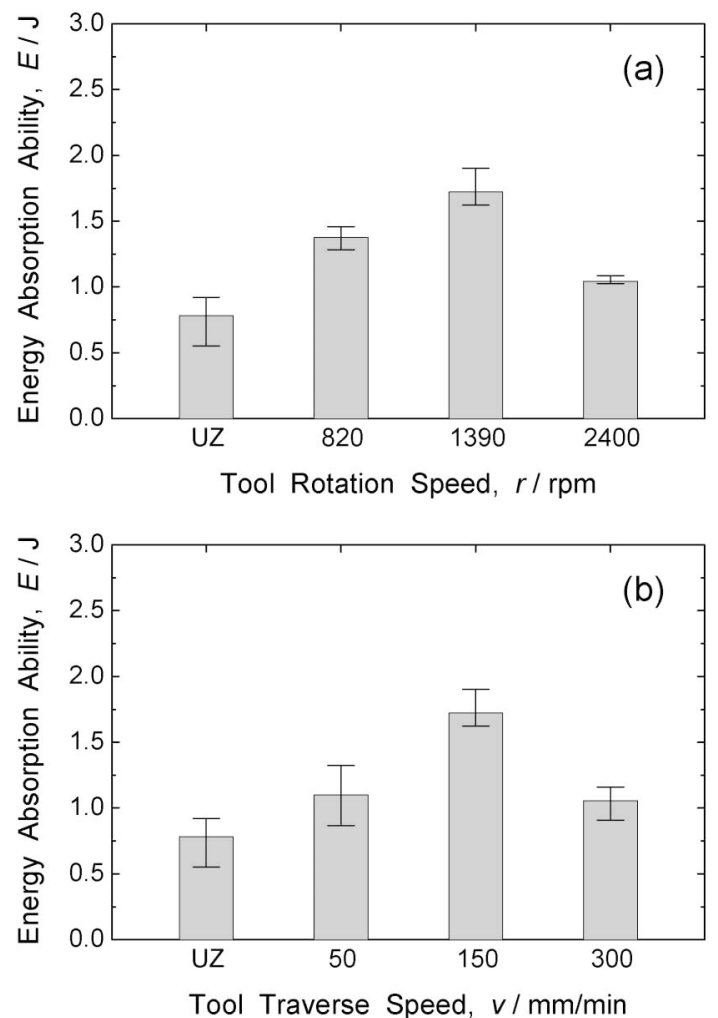

Fig. 8 Influences of (a) the tool rotation speed and (b) the tool traverse speed on the energy absorption ability of the surface-modified zone of the aluminum foams produced at the constant tool traverse speed of $150 \mathrm{~mm} / \mathrm{min}$ and tool rotation speed of $1390 \mathrm{rpm}$, respectively. The positive and negative error bars indicate the maximum and minimum values, respectively.

すべての表面改質条件において, 表面改質部が未加工部より 高い最大押込久加重を示した。特に，工具の移動速度および 回転速度がそれぞれ $150 \mathrm{~mm} / \mathrm{min}$ および $1390 \mathrm{rpm}$ であった 条件に颃いては，未加工部よりも約 2.2 倍高い最大押込久加 重を示し, 本研究において最も高い最大押込久加重が得られ た。

Fig. 8 は，(a)工具の回転速度および(b)工具の移動速度が アルミニウムフォームの表面改質部のエネルギー吸収能力に 及ぼす影響を示す。ここで $(\mathrm{a})$ 抢よび $(\mathrm{b})$ は，それぞれ工具 の移動速度を $150 \mathrm{~mm} / \mathrm{min}$ に一定とした場合および工具の 回転速度を $1390 \mathrm{rpm}$ に一定とした場合を示す。また，工 ラーバーは押し込み試験をそれぞれ 3 回ずつ行って得られ た最大值および最小值を示す．エネルギー吸収能力は，Fig. 6 に示した押込み試験に抢ける加重一変位曲線を積分するこ とにより得られた。 エネルギー吸収能力においても, Fig. 7 に示した最大押込み加重と同様に，すべての加工条件で表面 改質部が未加工部より高いエネルギー吸収能力を示した。 た, 工具の移動速度抢よび回転速度がそれぞれ $150 \mathrm{~mm} / \mathrm{min}$ および $1390 \mathrm{rpm}$ であった条件においては, 未加工部よりも 約 2.2 倍高いエネルギー吸収能力を示し, 本研究において最 も高いエネルギー吸収能力を示した.

これらの結果から, 本研究に打りる摩擦現象を利用したア ルミニウムフォーム表面改質プロセスは，アルミニウムフ オームの表面形状制御だけではなく, 最大押达久加重やエネ ルギー吸収能力などの機械的特性を向上することにより，ア
ルミニウムフォームの表面近傍における外力に対する変形抵 抗の向上に有効であり, 表面改質用工具の回転速度抢よび移 動速度は表面改質部の多様な特性に影響を及ぼす重要なパラ メータであることが明らかとなった。

\section{4. 結言}

本研究では, 高速回転する工具と多孔質金属材料との間で 起こる摩擦現象を利用してアルミニウムフォーム表面付近を 改質するとともに, 工具の回転速度掞よび移動速度が表面改 質部の表面形状，セル構造および機械的特性に及ぼす影響を 調べた. 以下に主な結果を示す.

（1）表面改質部の表面は，未加工部より平坦化されること により金属光沢が観察された．特に，工具の移動速度および 回転速度がそれぞれ $150 \mathrm{~mm} / \mathrm{min}$ 抢よび $1390 \mathrm{rpm}$ であった 場合において, 最も開気孔の少ない平坦な表面改質部が得ら れた。

(2) 高速回転する工具との摩擦により，アルミニウムフ オームの表面付近でセル構造が局部的に潰されるとともに, セル壁が塑性変形されることにより緻密な表面層を有する表 面改質部が形成された。

（3）表面改質部の最大押込久加重およびエネルギー吸収能 力はすべての加工条件において未加工部より向上できた. 特 に, 工具の移動速度および回転速度がそれぞれ $150 \mathrm{~mm} / \mathrm{min}$ および $1390 \mathrm{rpm}$ であった場合においては, 最大押込久加重 およびエネルギー吸收能力が未加工部よりそれぞれ約 2.2 倍 も向上できた.

（4）高速回転する工具と多孔質金属材料との間で起こる摩 擦現象を利用したアルミニウムフォーム表面改質プロセス は, アルミニウムフォームの表面形状制御だけではなく, 最 大押込久加重やエネルギー吸収能力などの機械的特性の向上 にも非常に有効であり, 表面改質用工具の回転速度および移 動速度は表面改質部の多様な特性に影響を及ぼす重要なパラ メータであることが明らかとなった。

本研究は, 2007 年蔚山大学研究費の支援を受けました.

文献

1) L. J. Gibson and M. F. Ashby: Cellular Solids: Structures and Properties, 2nd ed., (Cambridge University Press, Cambridge, 1997).

2) M. Ashby, N. Fleck, H. Wadley, J. Hutchinson and L. Gibson: Metal Foams: A Design Guide, (Butterworh-Heinemann, Boston, 2000)

3) J. Banhart: Prog. Mater. Sci. 46 (2001) 559-632.

4) F. Yi, Z. Zhu, F. Zu, S. Hu and P. Yi: Mater. Charact. 47 (2001) 417-422.

5) C. M. Moran, J. A. Ross, C. Cunningham, M. Butler, T. Anderson, D. Newby, K. A. A. Fox and W. N. McDicken: Ultrasound Med. Biol. 32(2006) 421-428.

6) Z. Xie, T. Ikeda, Y. Okuda and H. Nakajima: Mater. Sci. Eng. A 386 (2004) 390-395.

7) W. Jiejun, L. Chenggong, W. Dianbin and G. Manchang: Compos. Sci. 63(2003) 569-574.

8) T. Miyoshi, M. Itoh, S. Akiyama and A. Kitahara: Porous and Cellular Materials for Structural Applications, ed. D. S. Schwartz, D. S. Shih, A. G. Evans and H. N. G. Wadley, (MRS, San Fran- 
cisco, 1998).

9) L. Ma and Z. Song: Scr. Mater. 39(1998) 1523-1528.

10) A. E. Simone and L. J. Gibson: Acta mater. 46(1998) 31093123.

11) V. Gergely and T. W. Clyne: Adv. Eng. Mater. 2(2000) 175178.

12) V. Gergely, H. P. Degischer and T. W. Clyne: Comprehensive Composite Materials, Vol. 3: Metal Matrix Composites, ed. T. W. Clyne, (Elsevier, Amsterdam, 2000).

13) O. Prakash, H. Sang and J. D. Embury: Mater. Sci. Eng. A 199 (1995) 195-203.

14) Y. Sugimura, J. Meyer, M. Y. He, H. B. Smith, J. Grenestedt and A. G. Evans: Acta mater. 45 (1997) 5245-5259.

15) J. T. Beals and M. S. Thompson: J. Mater. Sci. 32 (1997) 3595-
3600.

16) W. Sanders and L. J. Gibson: Porous and Cellular Materials for Structural Applications, ed. D. S. Schwartz, D. S. Shih, A. G. Evans and H. N. G. Wadley, (MRS, San Francisco, 1998).

17) E. Andrews, W. Sanders and L. J. Gibson: Mater. Sci. Eng. A 270 (1999) 113-124.

18) H. Fusheng and Z. Zhengang: J. Mater. Sci. 34(1999) 291-299.

19) Y. J. Kwon, I. Shigematsu and N. Saito: J. Japan Inst. Metals 66 (2002) 1325-1332.

20) Y. J. Kwon, I. Shigematsu and N. Saito: J. Japan Inst. Metals 67 (2003) $547-554$.

21) T. Miyoshi, M. Itoh, S. Akiyama and A. Kitahara: Adv. Eng. Mater. 2(2000) 179-183. 